\title{
Do Self-ligating brackets increase the efficiency of orthodontic treatment?
}

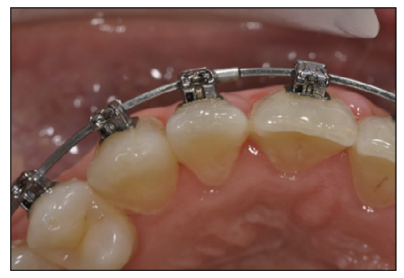

\section{An evidence-based review.}

\author{
Padhraig S. FLEMING ${ }^{1}$, Kevin O'BRIEN ${ }^{2}$ \\ ${ }^{1}$ Clinical senior lecturer/honorary consultant/Barts and the London School of Medicine \\ and Dentistry, London, United Kingdom \\ ${ }^{2}$ Professor of orthodontics, School of Dentistry, University of Manchester, Manchester, \\ UK
}

Reprint requests to: Padhraig S. Fleming, Barts and the London School of Medicine and Dentistry, Queen Mary University of London, Institute of dentistry, Turner street, London E1 2AD, United Kingdom; E-mail: padhraig.fleming@gmail.com

'This article was commissioned by Revue d'Orthopedie dent-faciale. It is an updated version of a paper by Fleming and O'Brien in the American Journal of Orthodontics and Dentofacial Orthopedics originally published in January 2013. The paper is reproduced with permission from Elsevier.'

\section{ABSTRACT}

Self-ligating brackets have become increasingly established in orthodontics in recent decades. While proponents haveprofessed overwhelming advantages of self-ligation, most notably a reduction in treatment time and a reduced requirement for extractions, there has been little convincing evidence to support many of these claims. In this review the evidence concerning the influence of self-ligating brackets on the efficiency of orthodontic treatment is considered.

\section{KEY WORDS}

Orthodontic

Bracket
Self-ligation

Efficiency
Address for correspondence:

\section{P. FLEMING}

Barts and the London School of Medicine and Dentistry,

Queen Mary University of London, Institute of dentistry,

Turner street, London E1 2AD, UK padhraig.fleming@gmail.com

Article available at nttp://Www.jdao-journal.org or nttp://dx.do
Article received: 03-2013. Accepted for publication: 05-2013. 
The Oxford English dictionary defines the efficiency of a system as one 'achieving maximum productivity with minimum wasted effort or expense'. Orthodontic pioneers have continuously sought methods of enhancing treatment efficiency by attempting to reduce the duration of orthodontic treatment and the length of orthodontic appointments ${ }^{26}$. While mean treatment times of 1 to $2^{22,27}$ years are now typical, the drive to reduce orthodontic treatment duration persists. A range of techniques and appliances, including surgical techniques $^{30}$; use of vibratory stimulation ${ }^{31}$, increased customisation of wires and brackets $^{23}$, eschewal of integral treatment phases ${ }^{32}$; and routine avoid- ance of extractions, continue to be proposed with the expressed aim of furthering this progression. The most high profile of these developments have been self-ligating brackets $(S L B s)^{33}$. The theoretical basis for reduced treatment time with SLBs was founded upon both secure, robust engagement facilitating efficient initial alignment and reduced friction accelerating space closure (Fig. 1). Unfortunately, the marketing of SLBs has courted courtesy with the advocates of this type of treatment being overly optimistic about their potential effects and, consequently, overlooking or ignoring the findings from clinical research studies ${ }^{17,21}$.

\section{CHAIRSIDE EFFICIENCY AND EASE OF USE}

There is plentiful evidence indicating that use of self-ligating systems results in a consistent but modest reduction in chair-side time over conventional appliances ${ }^{1,11,25,28,29,33}$ (Table I). In a meta-analysis ${ }^{2}$, results from two comparable studies ${ }^{28,33}$ were included reporting a mean time saving of 20 seconds per arch with slide opening compared with ligature removal. No significant time differ- ence was noted, however, for slide closure and replacement of ligatures. Proponents have suggested saved time could be availed of to schedule more patients; increase efficiency; improve patient relations; or allow oral hygiene reinforcement ${ }^{11}$. However, it could also be argued that a saving of 40 seconds per patient is insignificant and unlikely to change practice.

\begin{tabular}{|c|c|c|c|}
\hline Paper & SLB & Conventional mode of ligation & Saving \\
\hline Maijer and Smith $(1990)^{11}$ & SPEED ${ }^{\mathrm{TM}}$ & Elastomerics & 7 mins \\
\hline Shivapuja and Berger (1994) ${ }^{12}$ & Activa $^{T M}$, Edgelok $^{T M}$, Speed $^{T M}$ & Elastomerics Steel ligatures & $\begin{array}{l}1 \mathrm{~min} \\
12 \mathrm{mins}\end{array}$ \\
\hline Voudouris $(1997)^{13}$ & Interactwin ${ }^{\mathrm{TM}}$ & Elastomerics & $2.5 \mathrm{mins}$ \\
\hline Harradine $(2001)^{8}$ & Damon $\mathrm{SL}^{\mathrm{TM}}$ & Elastomerics & $25 \mathrm{sec}$ \\
\hline Berger and Byloff (2001) & SPEED ${ }^{\mathrm{TM}}$ & Elastomerics & $2.3 \mathrm{mins}$ \\
\hline Turnbull and Birnie $(2007)^{15}$ & Damon $2^{\mathrm{TM}}$ & Elastomerics & 1.5 mins \\
\hline
\end{tabular}

Table I

Comparative studies of chairside time differences with SLBs and conventional brackets (CBs). 

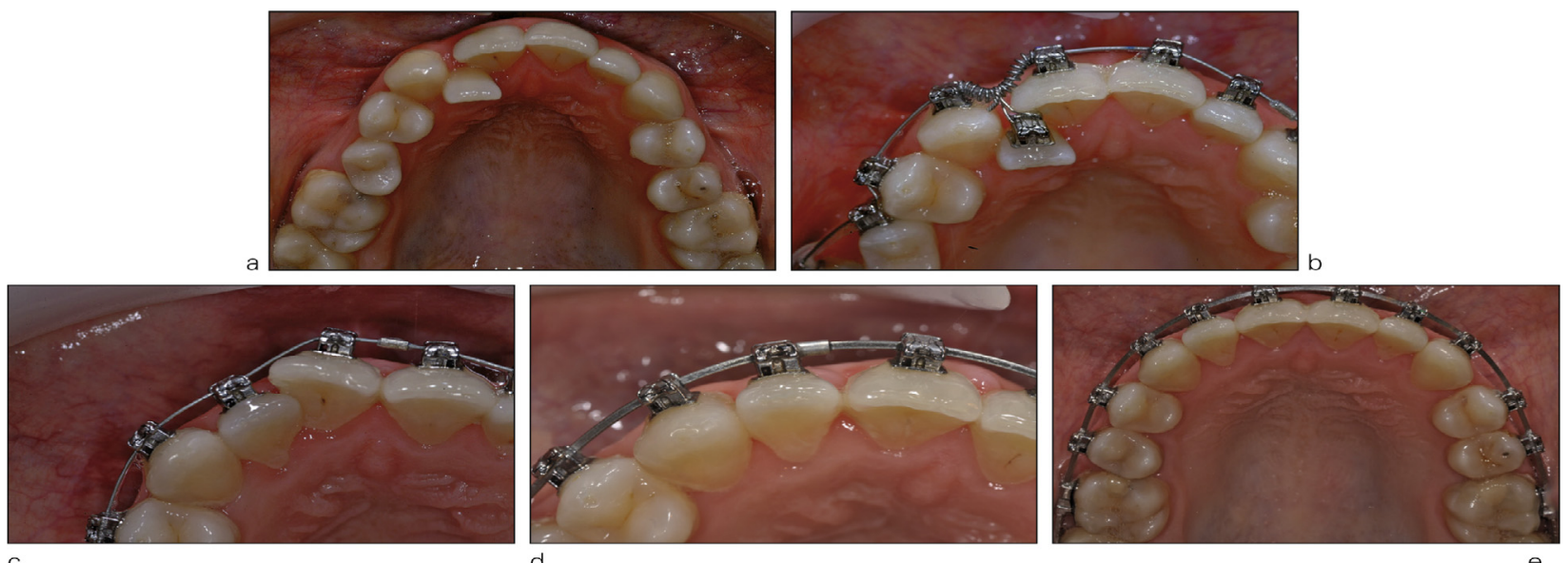

Figure 1

Alignment of severely crowded maxillary arch on a non-extraction basis can be undertaken with (a-e) or without (f-j) adjunctive use of NiTi coilspring to recreate space for excluded teeth. Alignment is facilitated by wire engagement afforded by the secure clip or gate mechanism of the self-ligating bracket.
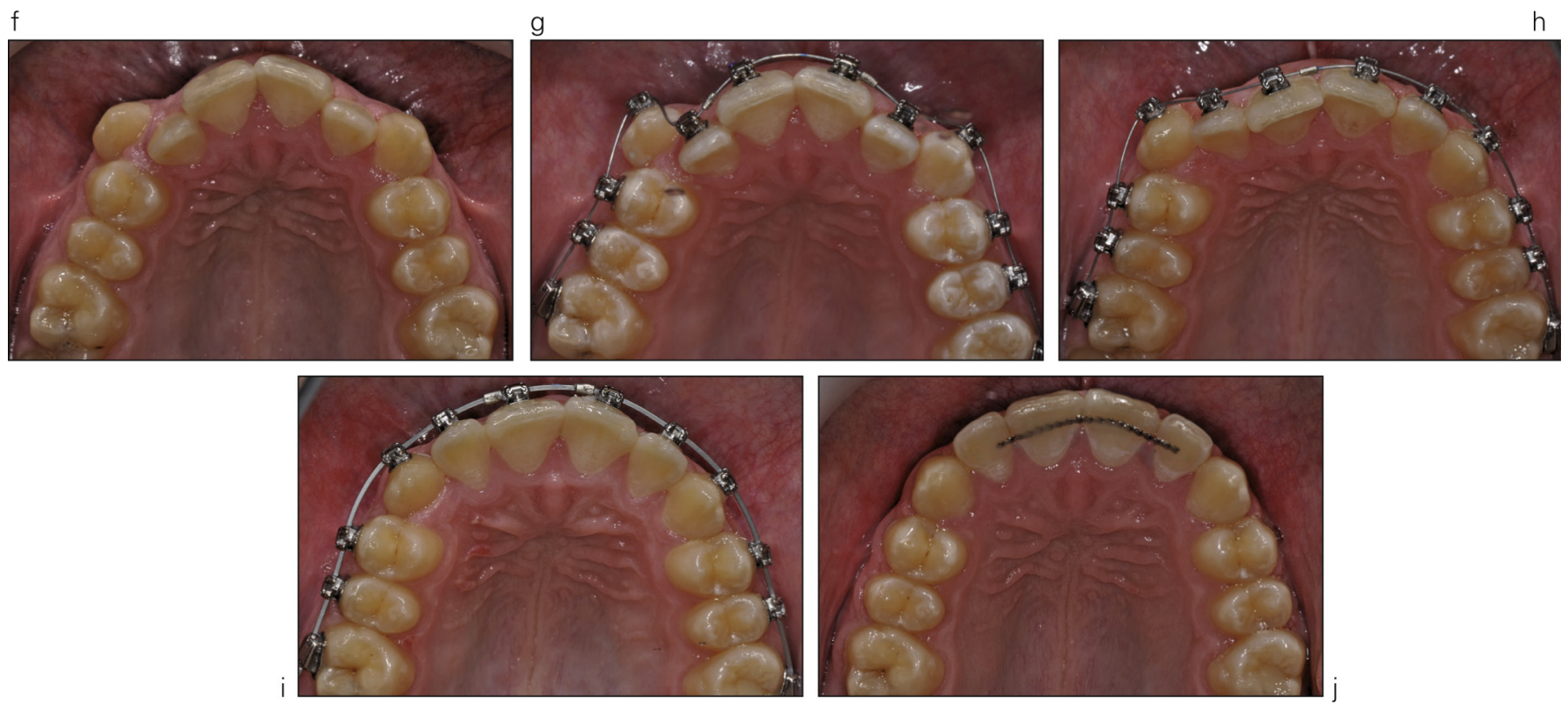

\section{EFFICIENCY OF TREATMENT}

Early research examining the relationship between self-ligating brackets and overall treatment time was observational rather than experimen- tal $^{4,6}$. Studies of this nature are invariably compromised by the compelling possibility of selection bias, observer bias and confounding including 
susceptibility to uncontrolled factors including varying operator experience and preference, differing arch wires and sequences, and inconsistent appointment intervals. These studies were most notable for the large discrepancy in treatment duration with mean treatments for conventional brackets ranging from $23.5^{6}$ to $31^{4}$ months. This discrepancy suggests that any advantage attributable to bracket type is likely to be dwarfed by extraneous factors including the skills, standards and ability of the operator. Nevertheless, the enduring message from these studies was

\section{EFFICIENCY OF ARCH ALIGNMENT}

A number of prospective studies have investigated the efficiency of initial orthodontic alignment over a period of up to 20 weeks 7,13,15,16,18-20,24. The results from these trials have consistently indicated that despite their associated costs self-ligating brackets may offer no advantage with respect to treatment efficiency (Table II).

For example, in a prospective analysis of 48 participants, Miles $(2005)^{13}$ compared alignment efficiency wth SmartClip ${ }^{\mathrm{TM}}$ and conventional twin brackets. SmartClip ${ }^{T M}$ was found to be no more effective at reducing irregularity during the initial stage of treatment than the conventional twin bracket ligated with elastomeric modules or stainless steel ligatures, with slightly more irregularity remaining after initial alignment in the group treated with SmartClip ${ }^{\mathrm{TM}}$; this was attributed to the rotational play allowed by the passive self-ligat- that SLBs were responsible for significantly reducing treatment times and visits without impairing the occlusal outcome. This assumption remained unchallenged until more robust prospective research began to emerge 4 years later. This prospective research was initially restricted to efficiency during a snapshot of treatment, including the efficiency of initial orthodontic alignment $7,13,15,16,18-20,24$ and the rate of orthodontic space closure $^{12,14}$ however, prospective studies encompassing treatment in its entirety have emerged more recently.

ing system using a 0.014 inch aligning NiTi wire. This study was limited by a small sample size; two-dimensional measurement; inclusion of both extraction and non-extraction cases; and confinement of measurement to the labial segment only. These findings were mirrored by Scott et al. ${ }^{24}$ in a randomized controlled trial of Damon $3^{\mathrm{TM}}$ and a conventional appliance in subjects treated with mandibular first premolar extraction. In a further clinical investigation of 58 patients, Miles et al. $(2006)^{15}$ compared efficiency of alignment and patient comfort related to Damon $2^{\mathrm{TM}}$ and a conventional twin bracket in non-extraction cases, using a split-mouth study design. At 10 week and 20 week intervals the twin bracket had achieved an irregularity index of $0.2 \mathrm{~mm}$ lower than Damon $2^{\mathrm{TM}}$ brackets.

Similar findings were reported by Pandis et al. $(2007)^{20}$ in a controlled 


\begin{tabular}{|c|c|c|c|c|}
\hline Study & Methods & Subjects & Interventions & Outcomes \\
\hline Miles $(2005)^{19}$ & $\begin{array}{l}\text { CCT, } \\
\text { Observed at } \\
10 \text { and } 20 \\
\text { weeks }\end{array}$ & $\begin{array}{l}48 \text { patients. } \\
\text { Mean age } 17.1 \\
\text { years, } 26 \text { male, } \\
32 \text { female }\end{array}$ & $\begin{array}{l}\text { Group 1: } 24 \text { patients } \\
\text { with SmartClip } \\
\text { Group 2: } 24 \text { patients } \\
\text { with Victory }^{\mathrm{TM}}\end{array}$ & $\begin{array}{l}\text { - Rate of initial alignment } \\
\text { lower 3-3 }\end{array}$ \\
\hline $\begin{array}{l}\text { Miles et al. } \\
(2006)^{20}\end{array}$ & $\begin{array}{l}\text { CCT, split- } \\
\text { mouth design, } \\
\text { Observed at } \\
10 \text { and } 20 \\
\text { weeks }\end{array}$ & $\begin{array}{l}58 \text { consecutive } \\
\text { patients. Mean } \\
\text { age } 16.3 \text { years, } \\
18 \text { male, } \\
40 \text { female }\end{array}$ & $\begin{array}{l}\text { Lower appliance } \\
\text { with Damon } 2^{\mathrm{TM}} \text { or } \\
\text { Victory }{ }^{\mathrm{TM}} \text { brackets in } \\
\text { alternate quadrants }\end{array}$ & $\begin{array}{l}\text { - Rate of initial alignment } \\
\text { lower 3-3 }\end{array}$ \\
\hline $\begin{array}{l}\text { Pandis et al. } \\
(2007)^{21}\end{array}$ & $\begin{array}{l}\text { CCT, } \\
\text { Observed } \\
\text { until alignment } \\
\text { achieved }\end{array}$ & $\begin{array}{l}54 \text { patients. } \\
\text { Mean age } 13.7 \\
(1.38) \text { years, } \\
11 \text { male, } 43 \text { female }\end{array}$ & $\begin{array}{l}\text { Group 1: } 27 \text { patients } \\
\text { with Damon } 2^{\mathrm{TM}} \\
\text { Group 2: } 27 \text { patients } \\
\text { with Microarch }\end{array}$ & $\begin{array}{l}\text {-Time taken (days) to } \\
\text { align lower 3-3 }\end{array}$ \\
\hline $\begin{array}{l}\text { Scott et al. } \\
(2008)^{22}\end{array}$ & $\begin{array}{l}\text { RCT, } \\
\text { Observed at } \\
8 \text { weeks and } \\
\text { following } \\
\text { mandibular } \\
\text { alignment }\end{array}$ & $\begin{array}{l}62 \text { patients } \\
\text { recruited. Mean } \\
\text { age } 16.27 \text { ( } 4.47) \\
\text { years, } 32 \text { male, } \\
30 \text { female }\end{array}$ & $\begin{array}{l}\text { Group 1: } 33 \text { patients } \\
\text { with Damon } 3^{\mathrm{TM}} \\
\text { Group 2: } 29 \text { patients } \\
\text { with Synthesis }^{\mathrm{TM}}\end{array}$ & $\begin{array}{l}\text { - Rate of initial alignmen } \\
\text { lower } 3-3 \\
\text {-Time taken (days) to } \\
\text { align lower arch in } 0.019 \\
\text { X 0.025" SSW }\end{array}$ \\
\hline $\begin{array}{l}\text { Fleming et al. } \\
(2009)^{23}\end{array}$ & $\begin{array}{l}\mathrm{RCT}, \\
\text { Observed at } \\
8 \text { weeks }\end{array}$ & $\begin{array}{l}65 \text { patients. } \\
\text { Mean age } 16.28 \\
(2.68) \text { years, } \\
22 \text { male, } 43 \text { female }\end{array}$ & $\begin{array}{l}\text { Group 1: } 32 \text { patients } \\
\text { with SmartClip } \\
\text { Group 2: } 33 \text { patients } \\
\text { with Victory }^{\mathrm{TM}}\end{array}$ & $\begin{array}{l}\text { - Rate of initial alignment } \\
\text { lower 6-6 }\end{array}$ \\
\hline $\begin{array}{l}\text { Miles and } \\
\text { Weyant }(2010)^{24}\end{array}$ & $\begin{array}{l}\text { RCT, } \\
\text { Observed at } \\
10.7 \text { weeks }\end{array}$ & $\begin{array}{l}60 \text { patients. } \\
22 \text { male, } 38 \text { female }\end{array}$ & $\begin{array}{l}\text { Group 1: } 30 \text { patients } \\
\text { with InOvation } \mathrm{C}^{\mathrm{TM}} \\
\text { Group 2: } 30 \text { patients } \\
\text { with Clarity }\end{array}$ & $\begin{array}{l}\text { - Rate of initial alignment } \\
\text { upper 3-3 }\end{array}$ \\
\hline $\begin{array}{l}\text { Ong et al. } \\
(2010)^{25}\end{array}$ & $\begin{array}{l}\text { CCT, } \\
\text { Observed at } \\
10 \text { and } 20 \\
\text { weeks }\end{array}$ & $\begin{array}{l}50 \text { patients. } \\
20 \text { male, } 30 \text { female }\end{array}$ & $\begin{array}{l}\text { Group 1: } 40 \text { arches } \\
\text { with Damon3 } \\
\text { Group 2: } 44 \text { arches } \\
\text { with CBs ( } 26 \\
\text { Victory }^{\mathrm{TM}}, 18 \\
\text { MiniDiamond }^{\mathrm{TM}} \text { ) }\end{array}$ & $\begin{array}{l}\text { - Rate of initial alignment } \\
\text { upper and lower 3-3 }\end{array}$ \\
\hline $\begin{array}{l}\text { Pandis et al. } \\
(2011)^{25}\end{array}$ & $\begin{array}{l}\text { RCT, } \\
\text { Observed at } \\
10 \text { and } 20 \\
\text { weeks }\end{array}$ & $\begin{array}{l}50 \text { patients. } \\
17 \text { male, } 33 \text { female }\end{array}$ & $\begin{array}{l}\text { Group 1: } 25 \text { arches } \\
\text { with Damon3 } \\
\text { Group 2: } 25 \text { arches } \\
\text { with Microarch }\end{array}$ & $\begin{array}{l}\text { - Rate of initial alignment } \\
\text { lower 3-3 }\end{array}$ \\
\hline
\end{tabular}

Table /I

Comparative studies of the rate of initial orthodontic alignment with SLBS and CBs. 


\begin{tabular}{|c|c|c|c|c|}
\hline Paper & $\mathbf{N}$ & SLB & Treatment time with SLBs & Treatment time with CBs \\
\hline Eberting et al., (2001) $)^{17}$ & 215 & Damon $\mathrm{SL}^{\mathrm{TM}}$ & 25 & 31 \\
\hline Harradine $(2001)^{18}$ & 60 & Damon $\mathrm{SL}^{\mathrm{TM}}$ & 19.4 & 23.5 \\
\hline Hamilton et al. $(2009)^{29}$ & 762 & InOvation ${ }^{\mathrm{TM}}$ & 15.5 & 15.8 \\
\hline${ }^{*}$ Fleming et al., $(2010)^{30}$ & 54 & SmartClip ${ }^{\mathrm{TM}}$ & 21 & 18 \\
\hline${ }^{*}$ DiBiase et al., $(2011)^{31}$ & 48 & Damon $3^{\mathrm{TM}}$ & 24.48 & 23 \\
\hline *Johannson and Lundstrom (2012) ${ }^{32}$ & 90 & Time $2^{\mathrm{TM}}$ & 20.4 & 18.2 \\
\hline
\end{tabular}

* Prospective study

Table III

Summary of average treatment times in comparative studies of conventional brackets (CBS) and SLBs.

clinical trial involving Damon ${ }^{\mathrm{TM}}{ }^{\mathrm{M}}$ and Microarch ${ }^{\mathrm{TM}}$ appliances when they reported no significant difference overall in the time taken to align the mandibular arch. A further randomized controlled trial $^{7}$ has reported little difference in alignment efficiency with an initial aligning wire (0.016 inch NiTi) with SmartClip ${ }^{\mathrm{TM}}$ and Victory ${ }^{\mathrm{TM}}$ systems in subjects treated without extraction. This study of 65 patients involved three-dimensional measurements and encompassed 11 mandibular contact points. Similarly, no difference in the rate of alignment could be attributed to ceramic SLBs compared to ceramic CBs in a further randomized controlled trial over a period of 10.7 weeks $^{16}$. Overall, these studies involving 397 participants indicate that, if any time saving does arise from use of self-ligating brackets, it does not become apparent in the initial alignment phase of treatment. However, alleviation of dental irregularity is difficult to measure perfectly; most trials have failed to control for individual metabolic variation; confounding may occur due to baseline imbalances; and the results may have been unintentionally biased by inaccurate bracket placement. In addition, split mouth designs may be criticised due to the complexity in handling residual malalignment between the central incisors. Nevertheless, on the basis of these prospective studies, it seems unlikely that self-ligating systems counterbalance their cost by resulting in more efficient treatment or better treatment outcomes.

\section{RATE OF SPACE CLOSURE AND CANINE RETRACTION}

This was first investigated by Miles $(2007)^{14}$ who considered the rate of orthodontic space closure in a splitmouth design negating the influence of metabolic variation. No statistical difference was found between the appliance types. This study had a relatively small sample size with 4 of 18 subjects failing to complete the study. Posted archwires were used on both sides; this design meant that rate of space closure on each side 
may also not have been completely independent of the opposing side. Nevertheless, these findings were reinforced by Mezomo et al. ${ }^{12}$ in a split-mouth RCT comparing the rate of canine retraction with either SmartClip ${ }^{\mathrm{TM}}$ or Gemini ${ }^{\mathrm{TM}}$ brackets on the canine tooth. Again, no clinically

\section{OVERALL TREATMENT DURATION}

Recently, a large retrospective study $^{29}$ and a number of RCTs ${ }^{30-32}$ investigating the duration of orthodontic treatment in its entirety have been published. The prospective studies were based in hospital or public health care settings and comprised a total of 192 participants (Table III). All three studies concluded that treatment with SLBs does not result in shorter treatment time. Importantly, they also included assessment of the quality of treatment outcome achieved using the PAR index ${ }^{3,8}$ or ICON score ${ }^{10}$. No statistical difference in treatment outcome was observed in any of the trials. These studies, therefore, indicate that SLBs are neither advantageous nor disad-

\section{CONCLUSION}

In total, 9 RCTs have been cited in this summary. There are also 2 published systematic reviews on SLBs ${ }^{2,9}$. It is, therefore, reasonable to assert that the question of whether SLBs improve treatment efficiency has been particularly well-researched in the context of orthodontic evidence. Furthermore, the consistency of the findings or statistically appreciable difference in the monthly rate of canine retraction was found; the average monthly rate of retraction was just $0.06 \mathrm{~mm}$ more with the SLB. Again these studies consistently indicate that SLBs may be of little benefit with respect to treatment efficiency.

vantageous in respect of treatment duration or outcome. Indeed, metaanalysis of the results from these studies indicates that treatment times might even be slightly lengthier with self-ligation (Fig. 2).

On the basis of this research it is doubtful whether a fixed appliance system may have a significant bearing on the duration of orthodontic treatment or on the number of visits required. Moreover, the skill, experience and objectives of the treating clinician in addition to the dictates of the presenting malocclusion are likely to override any potential difference in treatment efficiency due to bracket type.

from these prospective studies is remarkable, with none finding that SLBs translate into enhanced efficiency either during one phase of treatment or during overall therapy.

Therefore, despite the preliminary findings from retrospective studies, the contention that SLBs do not improve treatment efficiency is compelling, 


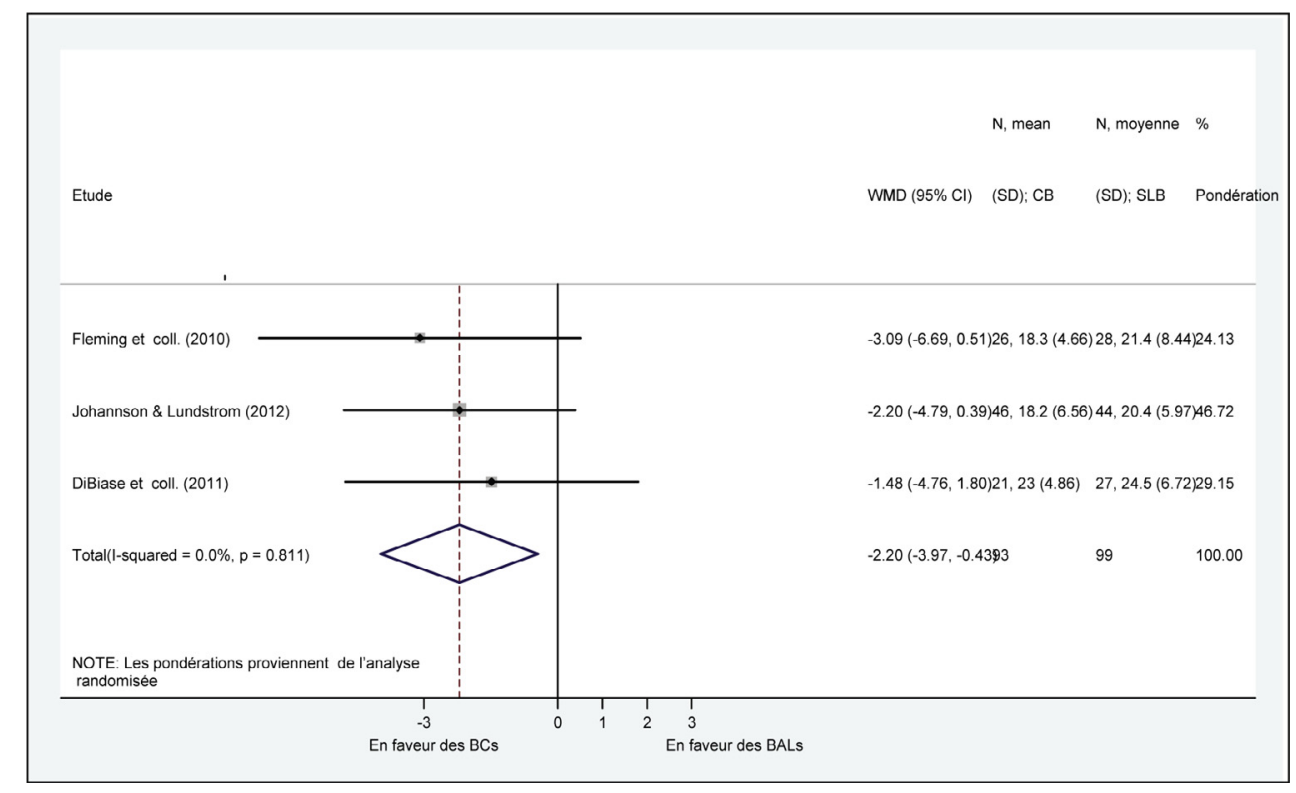

Figure 2

Meta-analysis and forest plot of overall treatment duration with self-ligating brackets (SLB) and conventional brackets $(C B)$.

highlighting the divergence between retrospective research and clinical reality. The efficiency of a course of orthodontic treatment is based on a complex interaction of parameters including appliance type; co-operation; biological age; and bone remodelling, with biological processes being the ultimate arbiter dictating the maximum speed of the process. While technological advances may sound and look alluring, osteoclasts are less easily impressed than clinicians. As our specialty progresses, further technological advancement, and greater intrusion from private companies with financial backing is inevitable. It is important that a degree of introspection occurs and that salutary lessons are learned when appraising the benefits of new, heavily-marketed appliance systems and "new' philosophies. We should not fall for the "Emperors New Clothes again".

\section{REFERENCES}

1. Berger JL, Byloff FK. The clinical efficiency of self-ligated brackets. J Clin Orthod 2001;35:304-8.

2. Chen S S-H, Greenlee MG, Kim JE, Smith CL, Huang GJ. Systematic review of selfligating brackets Am J Orthod Dentofacial Orthop 2010;137:726.e1-726.e18. 
3. Di Biase AT, Nasr IH, Scott P, Cobourne MT. Duration of treatment and occlusal outcome using Damon3 self-ligated and conventional orthodontic bracket systems in extraction patients: a prospective randomized clinical trial. Am J Orthod Dentofacial Orthop 2011;139:e111-e116.

4. Eberting JJ, Straja SR, Tuncay OC. Treatment time, outcome, and patient satisfaction comparisons of Damon and conventional brackets. Clin Orthod Res 2001;4: 228-234.

5. Hamilton R, Goonewardene MS, Murray K. Comparison of active self-ligating brackets and conventional pre-adjusted brackets. Aust Orthod J 2008;24:102-9.

6. Harradine NW. Self-ligating brackets and treatment efficiency. Clin Orthod Res 2001;4:220-227.

7. Fleming PS, DiBiase AT, Sarri G, Lee RT. Efficiency of mandibular arch alignment with 2 preadjusted edgewise appliances. Am J Orthod Dentofacial Orthop 2009;135: 597-602.

8. Fleming PS, DiBiase AT, Lee RT. Randomized clinical trial of orthodontic treatment efficiency with self-ligating and conventional fixed orthodontic appliances. Am J Orthod Dentofacial Orthop 2010;137:738-742.

9. Fleming PS, Johal A. Self-ligating brackets in orthodontics: a systematic review. Angle Orthod 2010;80:575-584.

10. Johannson K, Lundstrom F. Orthodontic treatment efficiency with self-ligating and conventional edgewise twin brackets A prospective randomized clinical trial. Angle Orthod 2012.

11. Maijer R, Smith DC. Time saving with self-ligating brackets J Clin Orthod 1990;24: 29-31.

12. Mezomo M, de Lima ES, de Menezes LM, Weissheimer A, Allgayer S. Maxillary canine retraction with self-ligating and conventional brackets. A randomized clinical trial. Angle Orthod 2011;81:292-7.

13. Miles PG. SmartClip versus conventional twin brackets for initial alignment: is there a difference? Aust Orthod J 2005;21:123-7.

14. Miles PG. Self-ligating vs conventional twin brackets during en- masse space closure with sliding mechanics. Am J Orthod Dentofacial Orthop 2007;132:223-5.

15. Miles PG, Weyant RJ, Rustveld L. A clinical trial of Damon2 vs conventional twin brackets during initial alignment. Angle Orthod 2006;76:480-485.

16. Miles P. Weyant R. Porcelain brackets during initial alignment: are self-ligating cosmetic brackets more efficient? Aus Orthod J 2010;26:21-6.

17. O' Brien K, Sandler J. In the land of no evidence, is the salesman king? Am J Orthod Dentofacial Orthop 2010;138:247-9.

18. Ong E, McCallum H, Griffin MP, Ho C Efficiency of self-ligating vs. conventionally ligated brackets during initial alignment. Am J Orthod Dentofacial Orthop 2010;138: e1-e7.

19. Pandis N, Polychronopoulou A, Katsaros C, Eliades T. Comparative assessment of conventional and self-ligating appliances on the effect of mandibular intermolar distance in adolescent nonextraction patients: a single-center randomized controlled trial. Am J Orthod Dentofacial Orthop 2011;140:e99-e105.

20. Pandis N, Polychronopoulou A, Eliades T. Self-ligating vs conventional brackets in the treatment of mandibular crowding: a prospective clinical trial of treatment duration and dental effects. Am J Orthod Dentofacial Orthop 2007;132:208-15.

21. Peck S. So what's new? Arch expansion, again. Angle Orthod. 2008;78:574-5.

22. Richmond S, Andrews M. Orthodontic treatment standards in Norway. Eur. J Orthod 1993;15:7-15

23. Saxe AK, Louie LJ, Mah J. Efficiency and effectiveness of SureSmile. World J Orthod 2010;11:16-22. 
24. Scott P, DiBiase AT, Sherriff M, Cobourne MT. Alignment efficiency of Damon3 selfligating and conventional ortho- dontic bracket systems: a randomized clinical trial. Am J Orthod Dentofacial Orthop 2008;134:470.e1-470.e8.

25. Shivapuja PK, Berger J. A comparative study of conventional ligation and self-ligation bracket systems Am J Orthod Dentofacial Orthop 1994;106:472-480.

26. Stolzenberg J. The Russell attachment and its improved advantages. Int J Orthodont Dent Child 1935;21:837-840.

27. Turbill EA, Richmond S, Wright JL. The time-factor in orthodontics: what influences the duration of treatments in the National Health Service practices? Community Dentistry and Oral Epidemiology 2001;29:62-72.

28. Turnbull NR, Birnie DJ. Treatment efficiency of conventional versus self-ligating brackets: the effects of archwire size \& material. Am J Orthod Dentofacial Orthop 2007; 131:395-399.

29. Voudouris JC. Interactive edgewise mechanisms: Form and function comparison with conventional edgewise brackets Am J Orthod Dentofacial Orthop 1997;111:119-40.

30. Wilcko WM, Wilcko T, Bouquot JE, et al. Rapid orthodontics with alveolar reshaping: two case reports of decrowding. Int J Periodontics Restorative Dent 2001;21:9-19.

31. http://acceledent.com/images/uploads/AcceleDent+Increases+the+Rate+of+Orthodontic+Tooth+Movement Results+of+a+RCT+Final+for+Print+November+14+2011. Pdf. Accessed 5th July, 2012.

32. http://www.6monthsmiles.com. Accessed 5th July, 2012.

33. http://www.damonbraces.com/choose/index.php. Accessed 5th July, 2012. 